УДК 616.12+616.12-009.72+616.12.-

КОЕФІЦІНТ УПОВІЛЬНЕННЯ СЕРЦЕВОГО РИТМУ - НОВІТНІЙ МЕТОД ПРОГНОЗУВАННЯ РАПТОВОЇ СЕРЦЕВОЇ СМЕРТІ

\title{
A.I. Витриховський
}

ВДНЗ «Івано-Франківський національний медичний університет», м. Івано-Франківськ, Україна

Ключові слова: фактори ризику, імемічна хвороба серия, аритмія, раптова сериева смерть, серичевий рumм.

Буковинський медичний вісник. T.22, № 1 (85). C. $9-16$

DOI:

10.24061/2413-0737. XXII.1.85.2018.2

\section{E-mail:}

vytryhovskiy@yahoo. com
Мета дослідження - розробка та впровадження концуепції профілактики фатальних ускладнень у популяиії осіб з високим $i$ дуже високим серцево-судинним ризиком на підставі комплексної оцінки стану варіабельності, турбулентності та величини коефіцієнта сповільнення сериевого ритму.

Матеріал і методи. У статті представлено аналіз 922 холтерівських моніторувань пацієнтів із постінфарктним кардіосклерозом та пацієнтів із високим і дуже високим ризиком виникнення сериево-судинних подій за шкалою SCORE.

Результати. Найбільший ризик виникнення життєво небезпечних аритмій та раптової сериевої смерті спостерігається серед осіб з дуже високим сериево-судинним ризиком, за шкалою SCORE (куриі тютюну), та супутнім явищем турбулентності сериевого ритму. В осіб із супутньою турбулентністю сериевого ритму спостерігається нижчий антифібриляторний захист парасимпатичної системи, ніж серед осіб без нього.

Висновок. При трансформації факторів ризику в захворювання серцево-судинної системи відбуваються зміни у вегетативній нервовій системі з втратою антифібриляторних властивостей організму.

\section{Ключевые \\ слова: факторь риска, ииемическая болезнь сердиа, аритмия, внезапная сердечная смерть, сердечный ритм.}

Буковинский медицинский вестник. T.22, № 1 (85). C. 9-16
КОЭФФИЦИЕНТ ЗАМЕДЛЕНИЯ СЕРДЕЧНОГО РИТМА - НОВЕЙШИЙ МЕТОД ПРОГНОЗИРОВАНИЯ ВОЗНИКНОВЕНИЯ ВНЕЗАПНОЙ СЕРДЕЧНОЙ СМЕРТИ А.И. Вытриховский

Цель исследования - разработка и внедрение концеепции профилактики фатальних осложнений в популяции людей с высоким и очень высоким сердечно-сосудистым риском на основании комплексной оценки состояния вариабельности, турбулентности и коэффициента замедления сердечного ритма.

Материал и методы. В статье представлен анализ 922 холтеровских мониторингов пациентов с постинфарктным кардиосклерозом, пациентов с высоким и очень высоким риском возникновения сердечно-сосудистых событий.

Результаты. Наибольиий риск возникновения жсизненно опасных аритмий и внезапной сердечной смерти наблюдаеться среди лиц с очень высоким сердечно-сосудистым риском, по шкале SCORE (курильщиики табака), и сопутствующим явленим турбулентности сердечного ритма. Наиболее неблагоприятным периодом времени в этом плане является ночной период. У лиц с турбулентностью сердечного ритма ниже антифибрилляторная защчита парасимпатической системь, чем среди лии без него. 
Вывод. При преобразовании факторов риска в заболевании сердечно-сосудистой системы происходит изменение в вегетативной нервной системе с потерей ее антифибрилляторных свойств.

Key words: riskfactors, ischemic heart disease, arrhythmia, sudden cardiac death, heart rhythm.

Bukovinian Medical Herald. V.22, № 1 (85). P. 9-16

\section{COEFFICIENT OF HEART RATE REDUCTION - THE NEWEST METHOD FOR PREDICTING THE SUDDEN CARDIAC DEATH}

A.I. Vytrykhovskyi

The objective is to develop and implement the concept of the prevention of fatal complications in populations of people with high and very high cardiovascular risk based on the assessment of the state of variability, turbulence of the heart rhythm and the coefficient of heart rate reduction.

Material and methods. The article presents an analysis of 922 Holter monitoring tests of patients with postinfarction cardiosclerosis in patients with high and very high risk of cardiovascula revents.

Results. The highest risk of life-threatening arrhythmias and sudden death is among those with very high cardiovascular risk of SCORE scale (tobacco smoker) and concomitant cardiac arrhythmia and heart rate turbulence. The most dangerous period for this - is the night period. People with turbulence in the heart rhythm have lower anti-fibrillation protection of the parasympathetic system, than among persons without it.

Conclusion. In the transformation of risk factors in the disease of the cardiovascular system there is a change in the autonomic system with the loss of anti-fibrilative properties of it.
Вступ. У 2006 році робочою групою електрофізіологів Мюнхенського університету (Schmidt G., Bauer A., Kantelhardt J.W.) встановлено новий підхід розмежування впливу на електрофізіологію серця симпатичної нервової системи та блукаючого нерва, використовуючи алгоритм обробки сигналу, що окремо характеризує уповільнення і прискорення потенціалу серцевого ритму (СР) [1]. Автори виявили, що зниження здатності уповільнення СР є потужним прогностичним фактором смертності після інфаркту міокарда (IM) і кращим, ніж фракція викиду лівого шлуночка (ФВ ЛШ) [2]. Отже, серед новітніх предикторів несприятливих наслідків після перенесеного IM та для оцінки вагусної модуляції СР запропоновано такий показник, як коефіцієнт уповільнення серцевого ритму - deceleration capacity (DC), який визначається методом Phase-rectified signal averaging (PRSA) [3]. Дана електрофізіологічна методика дозволяє оцінювати закономірності прискорення і сповільнення СР в умовах невизначеності фази наступної хвилі ритму серця, для цього вибирають як прив'язку певну фазу коливального процесу і об'єднують окремі коливання, представивши їх як синфазні. Процес усереднення практично виключає особливості, які не мають повторень. Як вузлові точки відліку (anchor) запропоновано використовувати точки, де спостерігається збільшення або зменшення значень часового ряду інтервалів RR (див. рис. 1.) Автори ввели найпростіші оцінні характеристики графіка PRSA, що відображають деякі адаптивні характеристики серця. У першу чергу розглядаються коефіцієнти уповільнення ритму - deceleration capacity (DC), тобто, збільшення RR інтервалу i acceleration capacity (AC) у разі прискорення ритму [6]. Як оцінний показник приймається різниця між середнім значенням двох точок після вузлової точки (X (0), X (1)) та двох точок (X (-2), X (-1)) до вузлової точки (рис. 2). У роботі авторів найбільш ефективним у прогностичному сенсі виявився показник DC, який вказує сповільнення СР [1, 3].

Численні дослідження показали погіршення DC у постінфарктних пацієнтів, пов'язане з підвищеним ризиком появи нестійкої шлуночкової тахікардії, яка має схильність до трансформації в зворотню чи не зворотню фібриляцію шлуночків $[4,5,6]$. Вивчення вимірів на ЕКГ, тісно пов'язаних із шлуночковою ектопією, аналіз їх 
Original research

взаємозв'язку з вегетативною регуляцією дає підгрунтя для нових способів діагностики ризик-стратифікованих маркерів раптової серцевої смерті (РСС) [7]. На сьогодні одним із способів прогнозування РСС стала оцінка показників турбулентності серцевого ритму (ТСР) [8].

Аналіз ТСР проводиться на основі двох показників - початок турбулентності (turbulence onset) (TO) та нахил турбулентності (turbulenceslope) (TS). TO - це величина почастішання CР зразу після шлуночкової екстрасистолії (ШЕ), а TS - це інтенсивність сповільнення СР, яке наступає за його почастішанням (рис.3). ТО розраховується як співвідношення різниць між сумами значень перших двох синусових інтервалів RR, які виникають за шлуночковою екстрасистолією (ШЕ), i наступних двох синусових RR інтервалів перед ШЕ до суми двох синусових RR інтервалів до ШЕ, виражене у відсотках [9]. Для розрахунку TO використовувалась така формула :

$\mathrm{TO}(\%)=100 *\{\mathrm{RR}[1]+\mathrm{RR}[2])-(\mathrm{RR}[-3]+\mathrm{RR}[-$ 2]) $\} /(\mathrm{RR}[-3]+\mathrm{RR}[-2])$,

де RR-2 та RR-3 - перший та другий синусові RR інтервали, які передують ектопічному комплексу; RR-1 та RR-2 - перший та другий синусові RR інтервали, які ідуть зразу після компенсаторної паузи.

Для визначення TS (мc/RR) розраховується нахил змін RR інтервалів за допомогою прямих ліній регресії для кожних 5 RR інтервалів з наступHих 20 за компенсаторною паузою RR[1]+RR[5]), $\mathrm{RR}[2]+\mathrm{RR}[6]) \ldots \mathrm{RR}[16]+\mathrm{RR}[20])$. За значення TS приймається максимальний позитивний регресійний нахил. Параметри акселерації ( То $\leq-1,5)$ i децелерації ( Ts $\geq 2,5$ ) синусового циклу, які ідуть за передчасними шлуночковими скороченнями, $\epsilon$ нормальними. Почащення СР та наступне за ним короткочасне сповільнення вважається фізіологічною відповіддю на ШЕ [10]. Параметр акселерації (( То $<0,0)$ та То $\geq-1,5))$ або децелерації ( $(\mathrm{Ts}>0,5)$ та $(\mathrm{Ts}<2,5))$, які ідуть за передчасними шлуночковими скороченнями, вважаються дещо нижче норми. Якщо величина параметра акселерації складає (То > 0,0) або децелерації (Ts $<$ $0,5)$, які ідуть за передчасними шлуночковими скороченнями, то така ТСР є суттєво нижче норми i на таке явище треба звернути увагу, тому що ризик виникнення життєво небезпечної ектопії $\epsilon$ вкрай високий $[8,9]$. Згідно зі статистикою, кожна четверта практично здорова людина має відхилення з боку показників ТСР, а кожен 17-й - суттєві відхилення і відповідно високий ризик РСC $[6,8]$. За результатами проведеного нами дослідження, у 6\% практично здорових осіб має місце суттєве відхилення в параметрах акселерації або децелерації ТСР. Найвища поширеність ШЕ і ТСР була зафіксована серед пацієнтів, які курять, і вона становила 44,8\%. Найнижча поширеність даної патології встановлена в осіб 3 ішемічною хворобою серця (IXC) і становила $30,34 \%$, і в осіб з метаболічним синдромом - була в межах 36\%[10].

Комбінація коефіцієнта уповільнення серцевого ритму з показниками ТСР відображає важкий
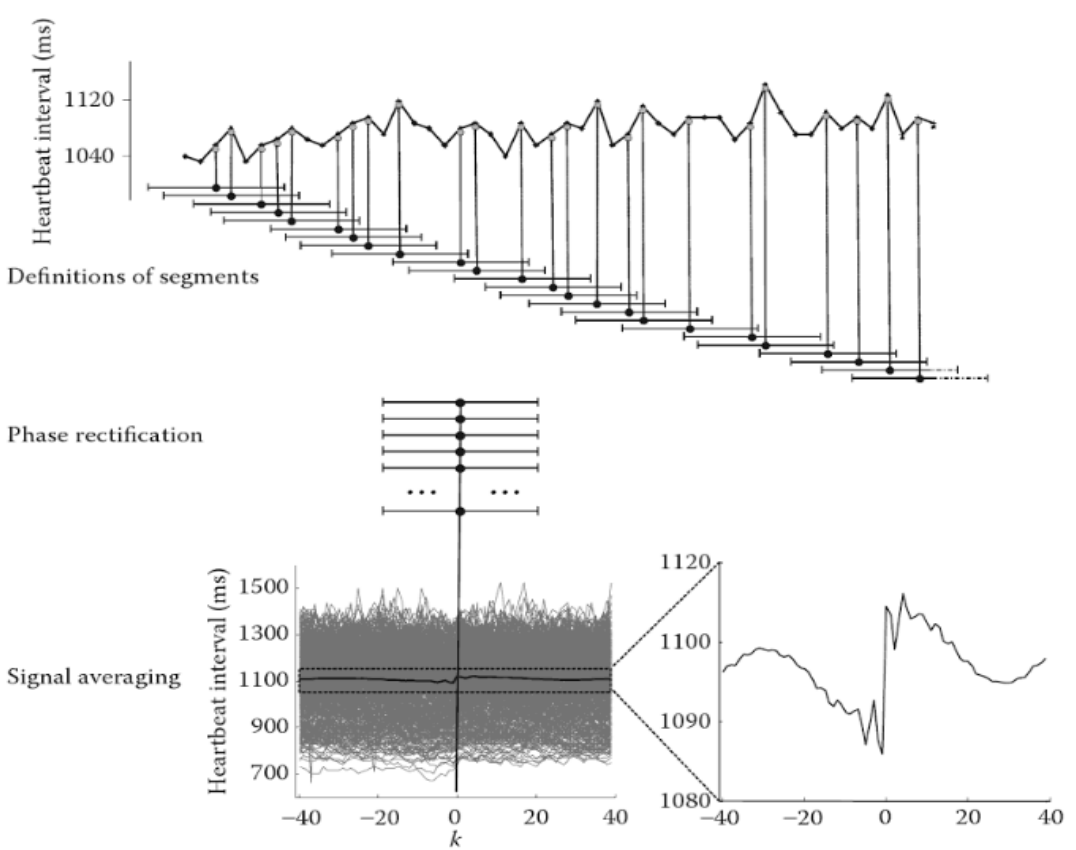

Рис. 1. Метод Phase-rectified signal averaging (PRSA) 


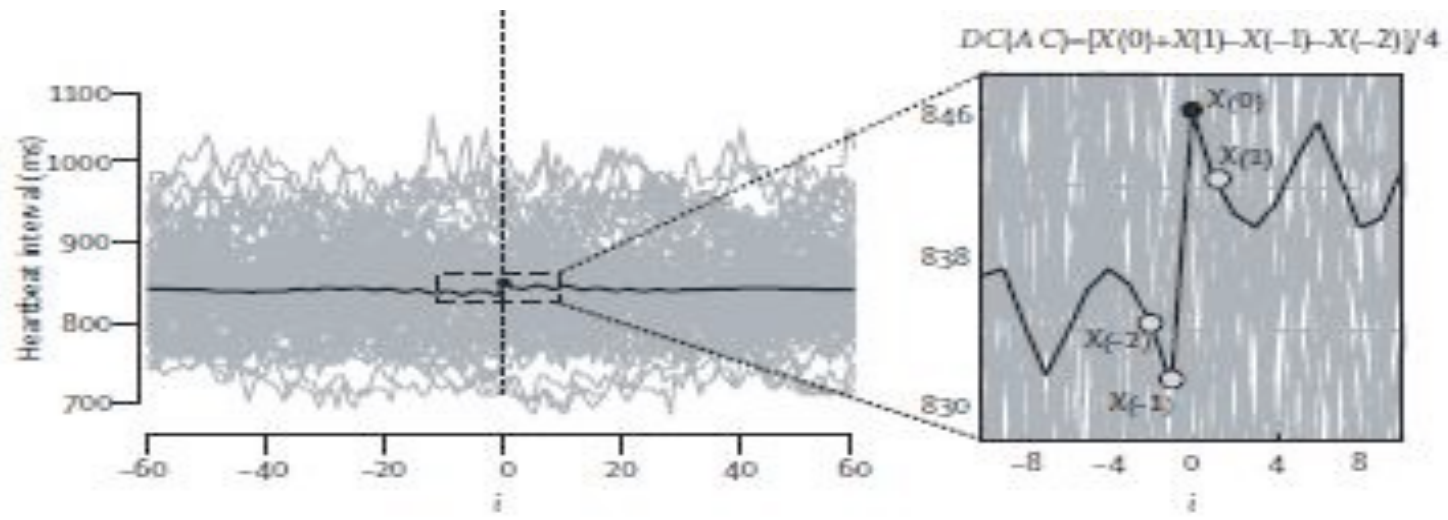

Рис. 2. Застосування методу PRSA

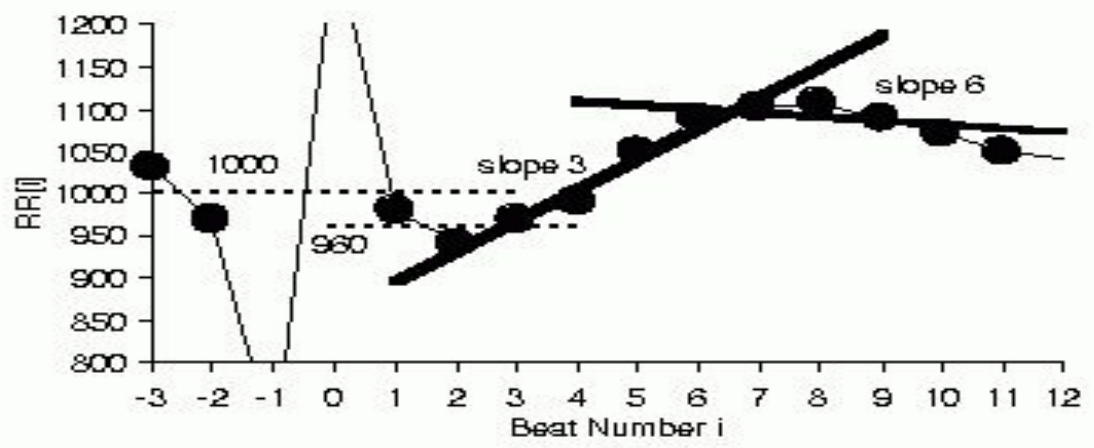

Рис. 3. Схема турбулентності серцевого ритму

вегетативний дисбаланс, навіть із збереженою функцією ФВ ЛШ у постінфарктних хворих [2, 4, $5,6]$. Недостатньо зрозуміло чи показник DC, крім загальної смертності в постінфарктних хворих, має будь-яку прогностичну здатність для прогнозування аритмічного ризику раптової смерті в пацієнтів із лише наявними факторами ризику розвитку серцево-судинних захворювань, щоб відповісти на це питання і було розроблено дане дослідження.

Мета дослідження - розробка та впровадження концепції профілактики фатальних ускладнень у популяції осіб із високим і дуже високим серцево-судинним ризиком на підставі комплексної оцінки стану варіабельності, турбулентності та величини коефіцієнта сповільнення серцевого ритму.

Матеріал і методи. За період 2007-2013 pр. обстежено 922 пацієнти віком від 35 до 85 років, яким проведено добове моніторування ЕКГ із вивченням варіабельності серцевого ритму (ВСР) та ТСР. Середній вік пацієнтів становив - 63,3 \pm 9,11 року. Гендерних чи вікових відмінностей між групами не було. Пацієнти досліджуваних груп, у свою чергу, були розподілені на підгрупи (в) і (т). Абревіатура в (ВСР) - означає, що в цих пацієнтів не спостерігалося порушень серцевого ритму за типом шлуночкової аритмії і відповідно в них не було наявного явища ТСР. Абревіатурою т (ТCР) проведено маркування показників ВСР у пацієнтів, в яких була наявна ШЕ різного ступеня градації.Всі пацієнти розподілені на групи: 1-ша - пацієнти з ішемічною хворобою серця (кардіосклероз постінфарктний), але без супутніх факторів ризику (куріння, ожиріння, метаболічний синдром), до цієї групи входили 72 пацієнти 3 ТСР та 163 - без ТСР. Середня ФВ ЛШ у 1-й (в) групі становила $(54,33+6,45) \%$, індекс маси тіла (IMT) - 25,1 2,9 кг/м2, середній артеріальний тиск (САТ) (систолічний / діастолічний) за даними добового моніторування артеріального тиску (ДМАТ) становив - 122,66+10,76/75,5+8,2 мм рт.ст. Середня ФВ ЛШ у 1-й (т) - 51,77+4,52 \%, індекс маси тіла (IMT) - 25,8土2,3 кг/м2, середній артеріальний тиск (САТ) (систолічний / діастолічний) за даними добового моніторування артеріального тиску (ДМАТ) був - 123,58+13,57/74,29+4,52 мм рт.ст. До 2-ї групи увійшли пацієнти, які курять тютюн, тривалістю більше двох років (особи 3 дуже високим кардіоваскулярним ризиком за 
Original research

шкалою SCORE), у цій групі було 69 осіб із ТCP i 85 осіб без цього явища. Середня ФВ ЛШ у групі контролю (в) -55,28+5,27 \%,IMT - 23,7 $\pm 3,8$ кг/ м2, САТ (систолічний / діастолічний) за результатами ДМАТ тримався в межах - 129,39+20,14/ $81,03+6,41$ мм рт.ст. У групі контролю (т) клінічні дані були такими: середня ФВ ЛШ становила

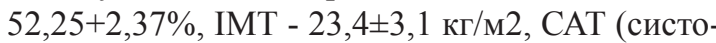
лічний / діастолічний) за результатами ДМАТ був на рівні - 131,27+11,41 / 91,81+2,28 мм рт.ст. До 3-ї групи увійшли пацієнти з метаболічним синдромом (особи з дуже високим кардіоваскулярним ризиком за шкалою SCORE), до цієї групи увійшли 138 осіб із ТСР та 246 - без ТСР. Середня ФВ ЛШ у групі контролю (в) - 52,25+2,37\%,

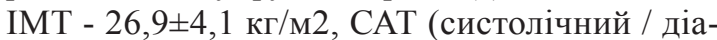
столічний) за результатами ДМАТ знаходився в межах - 143,68+17,45/ 79,81+11,08 мм рт.ст. У групі контролю (т) клінічні дані були такими:

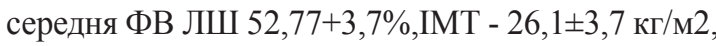
САТ (систолічний / діастолічний) за результатами ДМАТ - 142,37+16,93/ 81,62+11,49 мм рт.ст. До контрольної групи увійшли - у дослідженні ВСР 99 практично здорових осіб і в групі по дослідженню ТСР - 50 осіб. Середня ФВ ЛШ у групі

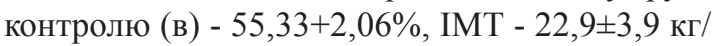
м2,САТ (систолічний / діастолічний) за результатами ДМАТ - 118,73+6,44/ 72,46+7,01 мм рт.ст. У групі контролю (т) клінічні дані були такими:

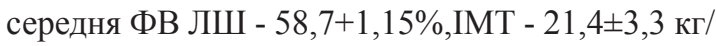
м2,САТ (систолічний / діастолічний) за результатами ДМАТ - 116,0+2,28/70,0+4,03 мм рт.ст.

У дослідження не входили хворі із супутніми ураженнями міокарда (гострим коронарним синдромом з елевацією та без елевації сегмента ST, вторинною артеріальною гіпертензією, постійною формою фібриляції чи тріпотіння передсердь), автоімунними, гематологічними захворюваннями, психічними розладами, з ендокринною патологі$€ ю$, пацієнти з гострою нирковою та печінковою недостатністю, агонуючі та онкологічні хворі, вагітні, спортсмени.

У дослідженні використовували результати обробки добових записів ЕКГ, виконання за допомогою системи холтерівського моніторування Cardiosens (Медика-XАI, м. Харків, Україна). Оцінку критеріїв прискорення (АС) і уповільнення (DC) ритму серця проводили за допомогою програми, написаної в середовищі Matlab 7.0 відповідно до формули, наведеної вище (PRSA алгоритм доступний для некомерційного використовування від www.prsa.eu). При виконанні роботи використаний оригінальний алгоритм, який розроблений Робочою Групою Біологічних сигналів Мюнхенського Технічного університету під керівництвом Professor Dr. Georg Schmidt (Working Group of Biological Signal Analyses in Technische Universität München) та затверджений International Society for Holter and Nonivasive Electrophysiology Consensus та American Heart Association/American College of Cardiology Foundation/Heart Rhythm Society Scientific у 2008 році. Коефіцієнти уповільнення ритму - deceleration capacity (DC) підрозділялися на низький (>4,5 мc), середній (4,5$2,5 \mathrm{Mc})$ і високий $(\leq 2,5 \mathrm{mc})$. Величина $\mathrm{DC} \leq 4,5$ мс вважалась паталогічною. Усі дані опрацювали за допомогою пакета прикладних і статистичних програм STATISTICA 10. Для всіх показників розраховували значення середньої арифметичної вибірки (М), iї дисперсії та похибки середньої (m). Для виявлення вірогідності відмінностей результатів досліджень визначали коефіцієнт Стьюдента

Таблиця 1

Характеристики основних груп хворих

\begin{tabular}{|c|c|c|c|c|c|c|}
\hline & $\begin{array}{c}\mathrm{AC}(\text { доба), } \\
\text { мс }\end{array}$ & $\begin{array}{c}\mathrm{DC} \\
\text { (доба), мс }\end{array}$ & $\begin{array}{c}\mathrm{AC} \\
\text { (день), мс }\end{array}$ & $\begin{array}{c}\mathrm{DC} \\
\text { (день), мс }\end{array}$ & $\begin{array}{c}\mathrm{AC} \\
\text { (ніч), мс }\end{array}$ & $\begin{array}{c}\mathrm{DC} \\
\text { (ніч), мс }\end{array}$ \\
\hline \multirow{2}{*}{ Контроль } & $-13,72 \pm$ & $15,1 \pm$ & $-11,61 \pm$ & $13,03 \pm$ & $-15,91 \pm$ & $17,47 \pm$ \\
& 0,69 & 1,02 & 0,42 & 0,62 & 1,02 & 1,53 \\
\hline \multirow{2}{*}{1 -ша (в) група } & $-9,21 \pm$ & $9,43 \pm$ & $-8,13 \pm$ & $8,63 \pm$ & $-10,14 \pm$ & $10,3 \pm$ \\
& $1,42^{1}$ & $1,71^{1}$ & $1,32^{1}$ & $1,69^{1}$ & $1,53^{1}$ & $1,79^{1}$ \\
\hline \multirow{2}{*}{ 2-га (в) група } & $-10,75 \pm$ & $11,87 \pm$ & $-10,12 \pm$ & $11,74 \pm$ & $-11,49 \pm$ & $12,69 \pm$ \\
& $0,42^{1}$ & $0,57^{1}$ & 0,42 & 0,69 & $0,42^{1}$ & $0,55^{1}$ \\
\hline 3-тя (в) група & $-9,72 \pm$ & $10,67 \pm$ & $-8,94 \pm$ & $10,38 \pm$ & $-10,61 \pm$ & $11,5 \pm$ \\
& $0,52^{2}$ & $1,01^{1}$ & $0,63^{1}$ & 1,34 & $0,47^{2}$ & $0,77^{1}$ \\
\hline
\end{tabular}

Примітки : 1 - різниця $\mathrm{p}<0,01$ між контрольною групою і досліджувальними групами. 2 - різниця $\mathrm{p}<0,001$ між контрольною і досліджувальними групами. 
(t), після чого визначали ймовірність відмінності вибірок (p) і довірчий інтервал середньої за таблицями розподілу Стьюдента. Вірогідними вважали значення, для яких $\mathrm{p}<0,05$.

Результати дослідження та їх обговорення. У таблиці 1 представлено порівняльна характеристика показників пришвидшення (AC) та уповільнення (DC) серцевого ритму серед осіб без супутнього явища ТСР. Загальнодобовий показник АС був у всіх досліджувальних групах вище контролю і якщо в 1-й (в) та 2-й (в) групах достовірність була (p < 0,01), то в 3-й (в) групі досягла рівня ( $<00001)$, а DC - достовірно нижче $(\mathrm{p}<0,01)$. Найвищі рівні $\mathrm{AC}$ та найнижчі DC коефіцієнтів зафіксовано у групі осіб із перенесеним у минулому IM, ще одною 3 особливостей цієї групи було те, що різниці між рівнями DC і AC коефіцієнтами практично не встановлено. Так, у контрольній групі (в) ця різниця становила - 1,38 мс, у 1-й (в) групі - 0,22 мс, у 2-й (в) групі - 1,12 мс, у 3-й (в) групі - 0,95 мс.Загальнодобові значення АС практично здо-

Таблиця 2

Коефіціснти уповільнення серцевого ритму серед осіб із супутнім явищем турбулентності серцевого ритму

\begin{tabular}{|c|c|c|c|c|c|c|}
\hline & $\begin{array}{c}\mathrm{AC} \\
\text { (доба), мс }\end{array}$ & $\begin{array}{c}\mathrm{DC} \\
\text { (доба), мс }\end{array}$ & $\begin{array}{c}\text { дАС (день), } \\
\text { мс }\end{array}$ & $\begin{array}{c}\mathrm{DC} \\
\text { (день), мс }\end{array}$ & $\begin{array}{c}\text { AC } \\
\text { (ніч), мс }\end{array}$ & $\begin{array}{c}\text { DC (ніч), } \\
\text { мс }\end{array}$ \\
\hline Контроль & $-10,5 \pm$ & $12,42 \pm$ & $-9,42 \pm$ & $11,47 \pm$ & $-11,68 \pm$ & $13,51 \pm$ \\
& 0,82 & 1,07 & 0,75 & 0,95 & 1,03 & 1,32 \\
\hline 1 -ша (т) & $-5,23 \pm$ & $6,25 \pm$ & $-5,27 \pm$ & $5,65 \pm$ & $-6,73 \pm$ & $7,21 \pm$ \\
група & $0,19^{1}$ & $0,32^{1}$ & $0,44^{1}$ & $0,33^{1}$ & $0,62^{1}$ & $0,86^{1}$ \\
\hline 2-га (т) & $-10,47 \pm$ & $10,81 \pm$ & $-9,73 \pm$ & $10,63 \pm$ & $-11,42 \pm$ & $11,5 \pm$ \\
група & $1,39^{2}$ & $1,35^{2}$ & $1,4^{2}$ & $1,58^{2}$ & $2,6^{2}$ & $1,97^{2}$ \\
\hline 3-тя (т) & $-11,2 \pm$ & $11,88 \pm$ & $-10,48 \pm$ & $11,1 \pm$ & $12,23 \pm$ & $13,07 \pm$ \\
група & $2,18^{2}$ & $2,0^{2}$ & $3,06^{2}$ & $2,79^{2}$ & $1,52^{2}$ & $1,47^{2}$ \\
\hline
\end{tabular}

Примітки : 1- різниця $\mathrm{p}<0,01$ між контрольною групою і 1,2,3-ю групами.

2 - різниця $\mathrm{p}<0,01$ між 1-ю групою 3 2,3-ю групами.

рових осіб і осіб 2-ї (т)групи були ідентичними, у 3-й (т) групі - недостовірно вищими, а в 1-й (т)групі - достовірно вищими $(\mathrm{p}<0,01)$. Достовірна різниця в загальнодобовій величині DC була зафіксовано лише в 1-й (т) групі. По групах загальнодобова різниця в DC і АС становила : у контрольній групі (т)- 1,98 мс, у 1-й (т) - 1,02 мс, у 2-й (т) - 0,34 мс , у 3-й (т) - 0,66 мс. В активний період доби показник АС був достовірно вищим у 1-й (т) групі (p < 0,01), у 3-й (т) групі недостовірно нижчим і в 2-й (т) майже ідентичний, як і в контролі. Що стосується DC показника, то в 2-й (т) та 3-й (т) групах він був недостовірно нижчим, ніж у контролі і з достовірністю $\mathrm{p}<0,01$ у 1 -й (т) групі був нижчим. По групах денна різниця в абсолютних величинах по DC i AC показниках становила : у контрольній групі (т) - 2,05 мс, у 1-й (т) - 0,38 мс, у 2-й (т) - 0,9 мс, у 3-й (т) - 0,62 мс. У пасивний період доби АС показник у контрольній і 2-й (т) групах були майже однаковими , у 3-й (т) групі він був недостовірно нижчим від контролю, а в 1-й (т) групі з достовірністю $(\mathrm{p}<0,01)$ був вищим. По групах нічна різниця в DC і AC становила: у контрольній групі (т - 1,83 мc, у 1-й (т) - 0,48 мс, у 2-й (т)-0,08 мс, у 3-й (т) - 0,84 мс. Аналіз порівняння показників АС та DC CP осіб із перенесеним у минулому гострим інфарктом міокарда із супутньою ТСР та осіб 3 факторами ризику розвитку серцево-судинних подій (2(т) та 3(т) групи) показав, що з однаковою

Таблиця 3

Відсоткове співвідношення осіб із патологічним рівнем коефіцієнта уповільнення ритму (DC)

\begin{tabular}{|c|c|c|}
\hline & DC ( без ТСР), \% & DC (з TCP), \% \\
\hline Контроль & 2,77 & 9,09 \\
\hline 1-ша група & 25 & 66,67 \\
\hline 2-га група & 17,86 & 32,14 \\
\hline 3-тя група & 4,5 & 25 \\
\hline
\end{tabular}


достовірністю $(\mathrm{p}<0,01)$ АС був нижчим, a DC вищим в обох групах. У таблиці 3 представлено відсоткове співвідношення осіб із паталогічним рівнем коефіцієнта уповільнення ритму (DC) до загальної кількості обстежених осіб у кожній 3 груп.

3 наведених даних у таблиці 3 можна бачити, що явище ТСР призводить до суттєвого підвищення кількості осіб з недостатньою вагусною модуляцією СР. Так, серед практично здорових осіб частота збільшується в 3,3 раза, серед осіб з перенесеним IM - у 2,6 раза, серед осіб з дуже високим серцево-судинним ризиком за шкалою SCORE - в 1,8 раза, серед осіб з високим ризиком - у 5,6 раза. Найвищий відсоток із прогностично-несприятливим рівнем DC був серед осіб із постінфарктним кардіосклерозом, і ця особливість проглядається в обох підгрупах, осіб з і без ТСР. Якщо порівняти статистичні дані осіб із дуже високим та високим серцево-судинним ризиком, то в обох підгрупах вищий відсоток спостерігався серед осіб із дуже високим серцево-судинним ризиком.

Власне, у роботі було встановлено, що серед осіб без супутнього явища ТСР найвищий рівень коефіцієнтів $\mathrm{AC}$ та найнижчий DC зафіксовано в групі осіб із перенесеним у минулому IM. При порівнянні груп із факторами ризику та перенесеному в минулому гострим IM достовірної різниці у величині даних коефіцієнтів немає. Можна стверджувати, що при трансформації факторів ризику в захворюванні серцево-судинної системи відбуваються зміни у вегетативній системі з поступовою втратою антифібриляторних властивостей організму. При аналізі показників АC та DC осіб із наявною ТСР встановлено такі особливості - у практично здорових осіб у нічний час, період фізіологічної парасимпатикотонії, різниця між показниками DC і AC наростає, то серед осіб із факторами ризику щодо виникнення серцево-судинних захворювань, навпаки, ця різниця зменшується. Особливо цей феномен характерний у 2-й групі серед осіб із ТСР. Отже, можна констатувати, що найбільш несприятливий період доби, щодо зниження антифібриляторного впливу на серце в осіб з дуже високим серцево-судинним ризиком (курців), є нічний період. Найвищий відсоток осіб iз прогностично-несприятливим рівнем DC був серед осіб із постінфарктним кардіосклерозом, i ця особливість проглядається в обох підгрупах, осіб з і без ТCР. Показники АC та DC у підгрупах iз ТСР були як в абсолютному, так і відносному значенні нижчими, ніж без ТСР.

Висновки

1. Найбільший ризик виникнення життєво небезпечних аритмій та раптової смерті є серед осіб із дуже високим серцево-судинним ризиком за шкалою SCORE ( курці тютюну) та супутнім явищем турбулентності серцевого ритму.

2. Достовірної різниці у величині коефіцієнтів прискорення чи сповільнення серцевого ритму в осіб із перенесеним у минулому інфарктом міокарда й осіб із факторами ризику розвитку серцево-судинних захворювань немає.

3. Найбільш несприятливим періодом доби, щодо виникнення життєво небезпечних аритмій, $€$ нічний період.

4. В осіб із турбулентністю серцевого ритму спостерігається нижчий антифібриляторний захист парасимпатичної системи, ніж серед осіб без нього.

Перспективи подальших досліджень. Важливим завданням $є$ удосконалення існуючих та пошук нових критеріїв для первинної профілактики раптової серцевої смерті, відокремлення контингенту пацієнтів з підвищеним ризиком раптової серцевої смерті.

Конфлікт інтересів відсутній.

\section{Список літератури}

1. Bauer A, Kantelhardt JW, Schmidt G, et al. Deceleration capacity of heart rate as a predictor of mortality after myocardial infarction: cohort study. Lancet. 2006; 367:1674-81.

2. Bauer A, Bathel P, Müller A, et al. Risk prediction by heart rate turbulence and deceleration capacity in postinfarction patients with preserved left ventricular function retrospective analysis of independent trials. J.Electrocardiol . 2009; 42: 597-601.

3. Bauer A, Morley-Davies A, Barthel P, et al.. Bivariate phase-rectified signal averaging for assessment of spontaneous baroreflex sensitivity pilot study of the technology. J. Electrocardiol. 2010;43:649-53.

4. Arsenos P, Gatzoulis K, Dilaveris P, et al. Arrhythmic sudden cardiac death: substrate, mechanisms and current risk stratification strategies for the post-myocardial infarction patient. Hellenic J.Cardiol. 2013;54:301-15.

5. Guzik P, Piskorski J, Barthel P. et al. Heart rate deceleration runs forpostinfarction risk prediction. J Electrocardiol. 2012; 45: P. 70-76.

6. Arsenos P, Manis G, Nikolopoulos S. Deceleration capacity alterations before nonsustained ventricular tachycardia episodes in post myocardial infarction patients. Computing in Cardiology. 2013;40:145-47.

7. Goldberger JJ, Cain ME, Hohnloser SH, et al. American Heart Association/American College of Cardiology Foundation/Heart Rhythm Society Scientific. Statement on noninvasive risk stratification techniques for identifying patients at risk for sudden cardiacdeath . J. Am CollCardiol. 2008; 52: 1179-99.

8. Gatzoulis K, Archontakis S, Dilaveris P, et al. Ventricular arrhythmias: from the electrophysiology laboratory to clinical practice. Part II: Potentially malignant and benign ventricular arrhythmias. Hellenic J. Cardiol. 2012;53:217-33.

9. Bauer A, Malik M, Schmidt G, et al. Heart Rate Tur- 
bulence: Standarts of Measurement, Physiological Interpretation, and Clinical Use. International Society for Holter and Nonivasive Electrophysiology Consensus. JACC. 2008; №52 (17): 1354-65.

10. Витриховський АI. Поширеність шлуночкової екстрасистолії та явища турбулентності серцевого ритму серед осіб з серцево-судинними захворюваннями та факторами ризику виникнення серцево-судинних подій за шкалою SCORE. Український терапевтичний журнал. 2017; 1: 57-65.

References

1. Bauer A, Kantelhardt JW, Schmidt G, et al. Deceleration capacity of heart rate as a predictor of mortality after myocardial infarction: cohort study. Lancet. 2006; 367:1674-81.

2. Bauer A, Bathel P, Müller A, et al. Risk prediction by heart rate turbulence and deceleration capacity in postinfarction patients with preserved left ventricular function retrospective analysis of independent trials. J. Electrocardiol . 2009; 42: 597-601.

3. Bauer A, Morley-Davies A, Barthel P, et al.. Bivariate phase-rectified signal averaging for assessment of spontaneous baroreflex sensitivity pilot study of the technology. J. Electrocardiol. 2010;43:649-53.

4. Arsenos P, Gatzoulis K, Dilaveris P, et al. Arrhythmic sudden cardiac death: substrate, mechanisms and current risk stratification strategies for the post-myocardial infarction patient. Hellenic J.Cardiol. 2013;54:301-15.

5. Guzik P, Piskorski J, Barthel P, et al. Heart rate deceleration runs forpostinfarction risk prediction. J. Elec- trocardiol. 2012; 45: P. 70-76.

6. Arsenos P, Manis G, Nikolopoulos S. Deceleration capacity alterations before nonsustained ventricular tachycardia episodes in post myocardial infarction patients. Computing in Cardiology. 2013;40:145-47.

7. Goldberger JJ, Cain ME, Hohnloser SH, et al. American Heart Association/American College of Cardiology Foundation/Heart Rhythm Society Scientific. Statement on noninvasive risk stratification techniques for identifying patients at risk for sudden cardiacdeath . J. Am CollCardiol. 2008; 52: 1179-99.

8. Gatzoulis K, Archontakis S, Dilaveris P, et al. Ventricular arrhythmias: from the electrophysiology laboratory to clinical practice. Part II: Potentially malignant and benign ventricular arrhythmias. Hellenic J. Cardiol. 2012; 53:217-33.

9. Bauer A, Malik M, Schmidt G, et al. Heart Rate Turbulence: Standarts of Measurement, Physiological Interpretation, and Clinical Use. International Society for Holter and Nonivasive Electrophysiology Consensus. JACC. 2008; №52 (17): 1354-65.

10. Vytryhovskiy A.I. Poshirenist' shlunochkovoï ekstrasistolii ta yavishcha turbulentnosti sertsevogo ritmu sered osib z sertsevo-sudinnimi zakhvoryuvannyami ta faktorami riziku viniknennya sertsevo-sudinnikh podii za shkaloyu SCORE [Distribution of phenomenon heart rate turbulence, among individual with risk factors of cardiovascular events].Ukraïns'kiy terapevtichniy zhurnal. 2017; 1: 57-65. (in Ukrainian).

\section{Відомості про автора:}

Витриховський Андрій Ігорович — к.мед.н., лікар-кардіолог вищої атестаційної категорії Івано-Франківського обласного клінічного кардіологічного диспансеру, асистент кафедри терапії та сімейної медицини, факультету післядипломної освіти, ДВНЗ «Івано-Франківський національний медичний університет» 76000 м. Івано-Франківськ, вул. Мазепи 114, Україна. Тел. 067-9563690. Ел. пошта: vytryhovskiy@yahoo.com

\section{Сведения об авторе:}

Вытриховский Андрей Игоревич - к.мед.н., врач-кардиолог высшей аттестационной категории Ивано-Франковского областного клинического кардиологического диспансера, ассистент кафедры терапии и семейной медицины, факультета последипломного образования, ГВУЗ «Ивано-Франковский национальный медицинский университет» 76000 г. Ивано-Франковск, ул . Мазепы 114, Украина. Тел. 067-956369.

Эл. почта: vytryhovskiy@yahoo.com

Information about the author:

Vytrykhovskyi Andrii Ihorovych — MD, PhD, Assistant, Department of Therapy and Family Medicine, Faculty of Postgraduate Education, Ivano-Frankivsk National Medical University, Cardiologist of higher attestation category, Ivano-Frankivsk Regional Clinical Cardiology Clinic, Ukraine. 76000. Ivano-Frankivsk, Mazepa Str. 114, Ukraine. Tel 067-9563690. E-mail: vytryhovskiy@yahoo.com

Надійшла до редакції 18.12.2017 Рецензент - проф. Тащук В.К. (C) A.I. Витриховський, 2018 